\title{
Preconditions and Implementation Paths of the Energy Cooperation between China and Central Asia--under the Background of New Silk Road Economic Belt
}

\author{
Gulinaer $Y_{\text {Yusufu }}^{1, a}$ \\ ${ }^{1}$ Xinjiang University Center for Innovation Management Research of Xinjiang, \\ School of Econimics \& Management, Urumqi, Xinjiang, 830047 \\ a email
}

Keywords: Energy Cooperation, Preconditions and Implementation Path, New Silk Road Economic Belt

\begin{abstract}
With the modernization of China's construction, the demand for energy is also increasing, Central Asia because it is rich in oil and become a big country to compete for land, but also China's energy diversification strategy of the inevitable choice. China is connected with the landscape of Central Asia, has a good geographical advantage. China and Central Asia in the Shanghai Cooperation Organization is to develop a good political relation, economic relations, which for further development of oil and gas cooperation laid the foundation. To protect the diversified energy import channels to ensure the safety of energy supply, stability is related to China's energy security and national development of the great cause of the important initiatives.
\end{abstract}

\section{Introduction}

From the analysis of China's energy, especially the supply of oil and natural gas, the demand situation analysis, on the one hand the supply of oil and gas resources growth is limited, on the other hand, energy demand continues to increase rapidly, import pressure increases. Specifically, the energy supply and demand imbalance caused by the main problems in the following areas: At present, China's crude oil self-sufficiency has almost reached the limit. According to the Ministry of Land and Resources statistics, as of the end of 2006, the national oil reserves of the remaining recoverable reserves of 2.043 billion tons, natural gas remaining recoverable reserves of 244.9 billion cubic meters; oil reserves ratio of 14.8, the development of oil reserves Only 10.9. In this storage and distribution ratio configuration, China's crude oil production has been in a critical state, and the future of domestic crude oil production is difficult to have a big breakthrough, oil and gas supply lag will become increasingly apparent, resulting in domestic oil and gas supply and demand gap will be year after year Increase, China's energy lifeline will become increasingly fragile. In order to meet domestic energy demand, make up the gap in energy supply, oil and gas energy imports will increase significantly. According to conservative estimates, in 2010 and 2020, China's crude oil imports will reach 150 million tons and 200 million tons respectively. This means that oil imports dependency will continue to increase. Since the 1990s, China's oil import dependence is increasing trend, in 1990 the import dependence is only 5.29\%, to 2006 has reached 47\%, 16 years increased by $41.71 \%$. Forecast shows that by 2010, China's dependence on foreign oil will be close to $50 \%$, 2020 foreign oil will reach $58 \%$. This means that more than half of China's oil consumption will have to rely on imports, oil supply and even economic development will greatly depend on the continued supply of foreign oil and oil market prices stable, China's energy security is facing severe challenges.

The so-called energy security is to ensure reliable and reliable supply of energy, mainly oil and natural gas reliable and reasonable supply. There is no uniform standard for energy safety. Some scholars have suggested that energy security and economic security can be divided into four grades according to the energy import dependency. The import dependency is less than $5 \%$, which belongs to the "safe" level; 5\% 10\% belongs to the "basic security" level ; 10\% to 15\%, are "unsafe" level; greater than 15\%, are "crisis" level. In terms of dependence on oil imports, combined with China's 
energy supply and demand and oil reserves and other factors.

According to the general equilibrium theory, commodity prices are determined by the supply and demand situation of buyers and sellers. As a special commodity, the price formation mechanism of oil has its particularity, its price depends not only on the supply and demand situation, but also by a country's economic strength, political influence, big country relations and other factors together. However, in any case, as a commodity, in the ideal market economy model, oil prices should also be the result of the balance of interests between oil-importing and exporting countries. However, the volatility of oil prices did not achieve the market economy of this resource allocation of the best results, in fact, China in the international oil pricing has long been passive acceptance, subject to the situation.

\section{Analysis on the Feasibility of Deepening Energy Cooperation between China and Central Asia}

International energy cooperation is not a purely economic issue, oil, natural gas as an important international energy cooperation target, whether the smooth output, the primary one can not be ignored is the geographical factors. How a country's geographical location and natural environment, what kind of neighboring countries, neighboring countries, what kind of political, economic, social situation, cultural background, and their relationship, will affect the two sides of the energy cooperation process. In terms of China's surrounding environment, the neighboring Central Asian countries in the west are a very important area, and the rich oil and gas resources in the region are directly related to China's energy security and economic development.

Central Asia is close to China's western Xinjiang, Kazakhstan, Kyrgyzstan and Tajikistan border with China, the two sides jointly owned more than 3,000 kilometers of the border line. Of which more than 1,700 kilometers in the border between China and Kazakhstan, Kyrgyzstan border more than 1,000 kilometers, 500 kilometers in the tower boundary. Turkmenistan and Uzbekistan, although not directly bordering China, but also adjacent to the country, the geographical advantage is also very obvious (see Appendix 2: Central Asia, the territory of five countries and China with the schematic diagram). The unique geographical environment of Central Asia has created a unique geographical relationship with China. Globalization and economic integration have greatly strengthened the influence of Central Asian countries, so that China and Central Asia's political and economic ties are increasingly close. At the same time, the traffic between Central Asia and the outside world is also increasingly developed. The main road trunk is from the Caspian Sea coast of Krasnowozsk as a starting point by Ashgabat, Chal Zhu, Tashkent, Almaty, and China Alashankou connected to the formation of Eurasian Continental Bridge, said the new Asia-Europe continent Bridge, which will be our economic hinterland and resource-rich Central Asia and the economically developed European market as a whole. There are two other rail lines: from Almaty to the north, through New Siberia, and across the Siberian railway; from Tashkent and Chaljou to the northwest extension of the Russian hinterland of Russia. Therefore, the long common border line, developed road traffic for China and Central Asia to deepen energy cooperation provides a natural geographical advantage.

In terms of China, China is a link between China's central and eastern regions and Central Asian countries. It has its own unique geographical advantages and plays an important and unique role in deepening the energy cooperation between China and Central Asian countries. Mainly in the following areas: First, Xinjiang vast land, rich in resources, oil, natural gas, coal and some important mineral resources in the country occupies a large proportion of China's important oil and gas production base and energy resources strategic base, Second, Xinjiang is located in the hinterland of the Eurasian continent, the East and the mainland of the mainland connected to the West and the tower, Kyrgyzstan, Kazakhstan three Central Asian countries border, as the west to the open bridgehead, It is an important gateway to the west of China. It is an important gateway to the westward opening of China. It is the transportation hub of energy transportation. Thirdly, there are 11 targets in Xinjiang, which are the important fulcrums of economic growth in western China. Five of the open countries of Central Asia, of which seven are for Kazakhstan, three for Kyrgyzstan and one for Tajikistan (see Appendix 3: China's Open Port for Central Asian Countries). Kazakhstan for 
the Alashankou port the largest volume, Horgos port is one of our few hundred years port, is the largest highway port in the northwest province. Alashankou less than 500 kilometers away from Urumqi, convenient rail transport will Xinjiang's political, economic, cultural center and the Central Asian market as a whole. Relying on the second Eurasian Continental Bridge efficient transport system will help the full development of rich natural resources in Central Asia, Urumqi's economic strength also to explore the potential of the Central Asian market play a clear supporting role.

Since the beginning of the 1990s, China's oil demand has increased rapidly, from the net oil exporting countries into a net oil importer, into the 21st century, is to become the world's second largest oil consumer. In order to meet domestic energy demand, the Chinese government began to implement the "going out" strategy, and actively expand overseas energy import channels. Including the expansion of energy import markets in Central Asian countries. China has made great efforts to establish diplomatic relations with Kazakhstan, tower, Kyrgyzstan, Ukraine and Turkey, and actively carried out energy cooperation on this basis, and made initial progress in more than ten years. The large-scale energy cooperation between China and Central Asia began in 1997.

\section{China and Central Asian Countries to Upgrade Energy Cooperation Channels}

In order to further cooperate with the Central Asian region, China should actively build a new cooperation mechanism to adapt to the current international situation. Silk Road Economic Zone has the establishment of a free trade zone, to improve China's energy investment in Central Asia to facilitate. First, investment, financing mechanism construction. Energy investment is different from other projects investment, according to the characteristics of energy investment, the construction of market-oriented energy price mechanism and energy operation mechanism, through the SCO development bank investment and financing to protect the project implementation process of funding needs, so that China And energy cooperation in Central Asia long-term sustained and healthy development. Second, the construction of the project evaluation mechanism. Any project will be carried out before the risk assessment, and then decide whether the program is worth implementation, so countries should join forces to form an expert assessment agencies to reduce the risk of project implementation and reduce losses to meet the economic needs of both partners. Third, the construction of information sharing mechanism. The Internet era, we should be based on the characteristics of this era, the development of relevant plans, through the Internet for the exchange between countries, while sharing the actual situation between countries, reduce the risk of investment. Fourth, the construction of dialogue and coordination mechanism. In order to achieve the purpose of winning a win-win situation between China and Central Asia, China through the construction of the Shanghai Cooperation Organization Energy Club, and actively organize energy management and energy companies to communicate, through peaceful means to solve the interests of countries caused by disputes.

With the gradual increase in energy trade between China and Central Asia, we should explore the development of new forms of trade cooperation: first, to explore the barter trade. China's light industry products (such as home appliances, plastic products, textiles, etc.) and agricultural products (such as flowers, dried fruits, vegetables, etc.) oversupply, while the Central Asian countries, light industry and agriculture is not developed, necessities and agricultural supplies supply, China can use Agricultural products and light industrial products to bargain with the energy of Central Asian countries. Second, explore the start of energy futures trading. As the capital technology-intensive industries of energy industry, pre-exploration and development and follow-up industrial upgrading, technological innovation and so need to invest a lot of money and investment return cycle is particularly long. Therefore, the energy companies in the capital often encounter shortages. China can try to carry out energy futures trading with Central Asian countries to meet the investment needs while avoiding risks, so as to grasp the pricing power in international energy cooperation.. Before we all share the way of energy cooperation with the Central Asian countries, mainly by the energy policy of Central Asian countries, it is difficult to implement the form of sole proprietorship. However, after the international financial crisis, the Central Asian countries look forward to the international capital injection of scarce energy in the field. Therefore, China should seize the 
opportunity to actively try to sole proprietorship in the Central Asian countries, oil and gas deep processing, energy exploration and development and other aspects of energy trade cooperation.

Central Asia's rich oil and gas resources make it the Eurasian continent, the Balkans, causing the world's major economies in the region's energy interests on the competition. According to the agreement signed by the SCO member states on the contents of the joint anti-terrorism and military joint exercises, it is necessary for China and the Central Asian countries to strengthen military exchanges, carry out military cooperation and increase energy security cooperation. China should provide In the military and technical aspects of the strong assistance to the religious extremist forces, violent terrorist forces, ethnic separatist forces in the three elements of the criminal activities in Central Asia to combat, to promote economic development, maintaining social stability, energy exploration and development to provide security The

\section{Conclusion}

Under the new situation, General Secretary Xi Jinping put forward the strategic conception of cross-Eurasia and Silk Road economic zone with the five countries of Central Asia, which brought new economic and trade cooperation between China and Central Asia in energy and other fields. vitality. With the sustained and rapid economic development, energy security has gradually become a key issue restricting China's economic development. Central Asia is close to China's geography, has an important strategic position and rich energy, the two sides can solve the problem of energy import countries in China a single, external dependence is too high and many other issues, the implementation of energy import market diversification strategy to improve China's energy security level , To build, the Silk Road economic belt, is of great significance.

\section{Acknowledgements}

Fund Project: National Social Science Fund Project (16BJL101); Humanities and Social Sciences Research Base Project for Universities in Xinjiang (010116B02)

\section{References}

[1] Xu Ying. China's three major public diplomacy highlights [J]. Today's China Forum, 2008 (Z1)

[2] Yang Cheng. The establishment of a unified energy space within the framework of the Shanghai Cooperation Organization [J]. Siberian Studies, 2008 (01)

[3] Willow. The Influence of Russian Energy Diplomacy on Sino-Russian Energy Cooperation [J]. Journal of Yunnan University of Finance and Economics, 2008 (01)

[4] Wei Jianlin. Energy and the international pattern [J]. Red Flag manuscript, 2008 (02)

[5] Yu Zhaohui. Integration of public diplomacy - the national image of the construction of a new perspective of strategic communication [J]. International observation, 2008 (01)

[6] Wang Xiaoying. Japan's energy diplomacy in Central Asia [J]. Journal of Heilongjiang Education Institute, 2007 (12) 